Назаревич Вікторія, кандидат психологічних наук, доцент кафедри вікової та педагогічної психології, Рівненський державний гуманітарний університет http://orcid.org/0000-0002-0111-7070 DOI https://doi.org/10.35619/praprv.v1i15.193

\title{
ОСТРАКІЗАЦІЯ ЯК ФЕНОМЕН ІНКЛЮЗИВНОГО ПРОСТОРУ
}

Анотація. Стаття вивчає явище остракізації як феномен інклюзивного простору. Особливу увагу приділено інтолерантності до індивідів з інклюзивними проявами, що існує в суспільстві, внаслідок взаємодї між людьми різних національностей, конфесій, професійного спрямування та певних фізичних особливостей. Автор розкриває розуміння явища остракізму в просторі освіти як процесу, який характеризується як розгортання послідовності відповідей: перенесених, ігнорованих та виключених. А також, як виключення, поодинці чи ізольовано, іноді з явними проявами неприязні.

Розкрито модель та особливості проявів феномена в просторі інклюзивної освіти, які включають: пригнічений емочійний стан індивіда під час навчального процесу або після перебування в академічній групі; потайливість, сором'язливість, тенденція до замовчування свого особистого життя; відхід від спілкування з сім'єю, друзями та спільної діяльності; уникання дискусій про університет або інше освітне середовище. Визначено, що основною причиною остракізації інклюзистів у середовищі освіти є сприйняття осіб з обмеженими можсливостями як феноменологічної групи «іншого», а причина иъого підходу полягає в механізмі страху «іншого» як прояву самозахисту. Вказано на гандикапні прояви остракізму - виключення із соиіального середовища під впливом психофізіологічних особливостей: мобінг, уникання, насмішки, потурання, наклеп.

Висвітлено основні умови організації інклюзивного процесу при роботі 3 остракізаторськими проявами в освітянській сфері: партнерство сім'ї та школи; співпраия між загальноосвітніми та дефектологами; узгоджене планування та спілкування між персоналом «загальних» та «особливих потреб». Наголошено на низиі позитивних наслідків включень, які впливають як на осіб з особливими потребами, так $і$ на інших учасників освітнього простору.

Зроблено висновки, щзо дотримання принщипів ведення інклюзивних осіб в освітньому просторі та забезпечення системного супроводу всього освітянського процесу дають змогу формувати тендениії до толерантного сприйняття «іншого», індивідуальних особистісних проявів та, як наслідок, мінімізації проявів остракізму як в інклюзивному просторі, так $i$ в закладах освіти без спеціалізованих класів. Подальший розгляд иієї проблеми вбачаємо в більш розгорнутому вивченні основних методів супроводу осіб з особливими потребами включення в освітній простір та можливостей формування тенденцій толерантного ставлення через включення у простір освіти інклюзивного індивіда.

Ключові слова: інклюзія, інклюзивний простір, толерантність, остракізм, прояви остракізму, мінімізація остракізму, виховна робота.

Постановка проблеми. Проблема соціального виключення осіб 3 особливими потребами в соціумі та безпосередньо в освітньому просторі стала актуальною в 80 -х роках $\mathrm{XX}$ століття. Погляди на соціальне виключення, що поширені сьогодні в науці, дещо різняться між собою. Неприйняття розглядається як неприпустима, нетерпима поведінка, неприйняття чужої думки; як риса, що зумовлює недопущення участі в будь-чому інших людей, які відрізняються від індивіда за певними ознаками.

Інтолерантність до індивідів з інклюзивними проявами, що існує в суспільстві, має свої культурно-історичні витоки. Внаслідок взаємодії між людьми різних національностей, конфесій, професійних спрямувань, певних фізичних особливостей склались певні відносини 
та сформувались стереотипи, які зумовили схематичне, спрощене сприйняття представників різних груп інклюзивного спрямування. На основі специфіки ідентичності формується толерантне чи інтолерантне ставлення до виразників різних груп, зокрема до людей 3 обмеженими фізичними можливостями. Якщо такі особи сприймаються як чужі, як представники іншої соціальної групи, до них часто виникають остракізовані прояви. Їх не приймають, сприймають як неповноцінних, наділяють негативними якостями, що є ознаками гандикапізму.

Остракізація є феноменом, що здійснює негативний вплив на суспільні відносини, призводить до погіршення соціальної ситуації як у міжособистісних стосунках, в освітньому просторі, так і в соціумі загалом. Вона провокує зростання напруженості, появу конфліктів, що можуть набувати національних масштабів. Найбільш небезпечним проявом цього феномена $\epsilon$ агресія щодо інвалідів, яка спрямована на завдання шкоди, провокацію негативних емоційних станів, а в крайніх випадках - на знищення іншого індивіда або групи. Слід також зазначити, що серед осіб з обмеженими можливостями часто спостерігаються прояви аутоагресії, коли людина не приймає сама себе, не може змиритися 3 фактом інвалідності та не має ресурсів для створення позитивного образу «Я». Такі індивіди особливо страждають від проявів гандикапізму, оскільки в них ослаблені механізми психологічного захисту; вони можуть опинитися на межі суїциду. Тому вивчення феномена остракізму в інклюзивному просторі є важливим аспектом пізнання зазначеного явища, а також механізмом попередження утворення остракізаторських тенденцій у закладах освіти щодо осіб з особливими потребами.

Аналіз останніх досліджень. Дослідження остракізму та його наслідків проводилися в різних формах: лабораторні експерименти (Stroud, 2000; Eisenberger, 2003), якісний аналіз (Zadro, Williams., 2006). Явище остракізму є поширеним і шкідливим в середовищі освіти (Williams, 2007; Eisenberger, 2003; Gunnar, 2003). Прояви остракізму здійснюють вплив на поведінку учасників освітянського процесу (Hitlan, 2006; Jones, 2009; Jahanzeb, 2018).

Інклюзія $є$ важливою частиною освітнього середовища (Пауелл, Лайл, 1997). Інклюзія досліджувалась і вивчалась десятиліттями, хоча серед громадськості це мало повідомлялося, з ранніми дослідженнями гетерогенних та однорідних груп умінь (Stainback, Stainback, 1989). Досліджували критичні наслідки та фасилітаторів інклюзії (Jorgensen, Tashie, 2000 ), самодостатність загальноосвітнього звороту в інклюзивному просторі (Fried, Jorgensen, 2008).

Формулювання мети статті. Здійснити теоретичний аналіз явища остракізму як феномена інклюзивного простору. Висвітлити основні положення наукових публікацій із вказаної теми.

Відповідно до зазначеної мети, було висунуто такі завдання: проаналізувати особливості явища остракізму в просторі освіти; розкрити модель та особливості причин і проявів феномена в просторі інклюзивної освіти; висвітлити основні умови організації інклюзивного процесу під час роботи з остракізаторськими проявами в освітянській сфері.

Виклад основного матеріалу дослідження. Остракізм трактується як процес, який характеризується як розгортання послідовності відповідей: перенесених, ігнорованих та виключених. Лабораторне дослідження остракізму вивчає наслідки ігнорування та виключення протягом декількох хвилин; але польові дослідження, дослідження щоденників та співбесіди вивчають остракізм протягом днів, тижнів та років (Stroud, 2000: 204 - 212). Зазначений феномен визначається як виключення, поодинці чи ізольовано, іноді з явними проявами неприязні до індивідів. Як правило, маніпуляція виключенням відбувається або після взаємодії та відокремлення від інших, або як гіпотетичний наслідок у майбутньому. Відмова зазвичай відбувається після взаємодії та ізоляції (Masten, 2011: 381 - 388). Ефекти явища остракізації різні, але дослідження засвідчують, що воно здійснює негативний вплив на молодь більшою мірою, ніж на осіб пубертатного або зрілого віку. Студентство часто страждає з більшою ймовірністю, оскільки особа цього вікового періоду проходить активний інтелектуальний і особистісний розвиток (Jones, 2009: 157 - 174). Остракізація індивідів 3 особливими потребами може виявлятись у пасивній чи активній формі. Пасивна - полягає в 
негативному ставленні до інвалідів, небажанні спілкуватися та взаємодіяти з ними. Активна форма виявляється у відкритих проявах агресії, таких як цькування, приниження, переслідування (Jahanzeb 2018: 430 - 440).

У контексті вивчення вказаної теми, важливо наголосити на ознаках соціальної ізоляції в освітньому середовищі для можливості попередження розвитку цього явища та вчасного психологічного втручання:

- пригнічений емоційний стан індивіда під час навчального процесу або після перебування в академічній групі;

- потайливість, сором'язливість, тенденція до замовчування свого особистого життя (Jones 2009: 157 - 174);

- $\quad$ відхід від спілкування з сім'єю, друзями та спільної діяльності;

- уникання особою групових зборів;

- різкі зміни в настрої, поведінці, сні або апетиті;

$204-212$ ).

- уникання дискусій про університет або інше освітнє середовище (Stroud 2000:

Наступним важливим аспектом під час дослідження цієї теми були причини соціального неприйняття осіб з особливими потребами. Майже всі ці чинники зосереджені навколо питання про те, як вони впливають на здатність індивіда брати участь в житті суспільства, та проблем ідентифікації себе з індивідами певної категорії - сприйняття осіб інклюзистів як феноменологічної групи «іншого» (Leary 2005: 381 - 388). Причина цього підходу полягає в механізмі страху «іншого» як прояву самозахисту (див. рис. 1).

Інклюзія - включення в систему загальноосвітнього простору особи з особливими потребами.

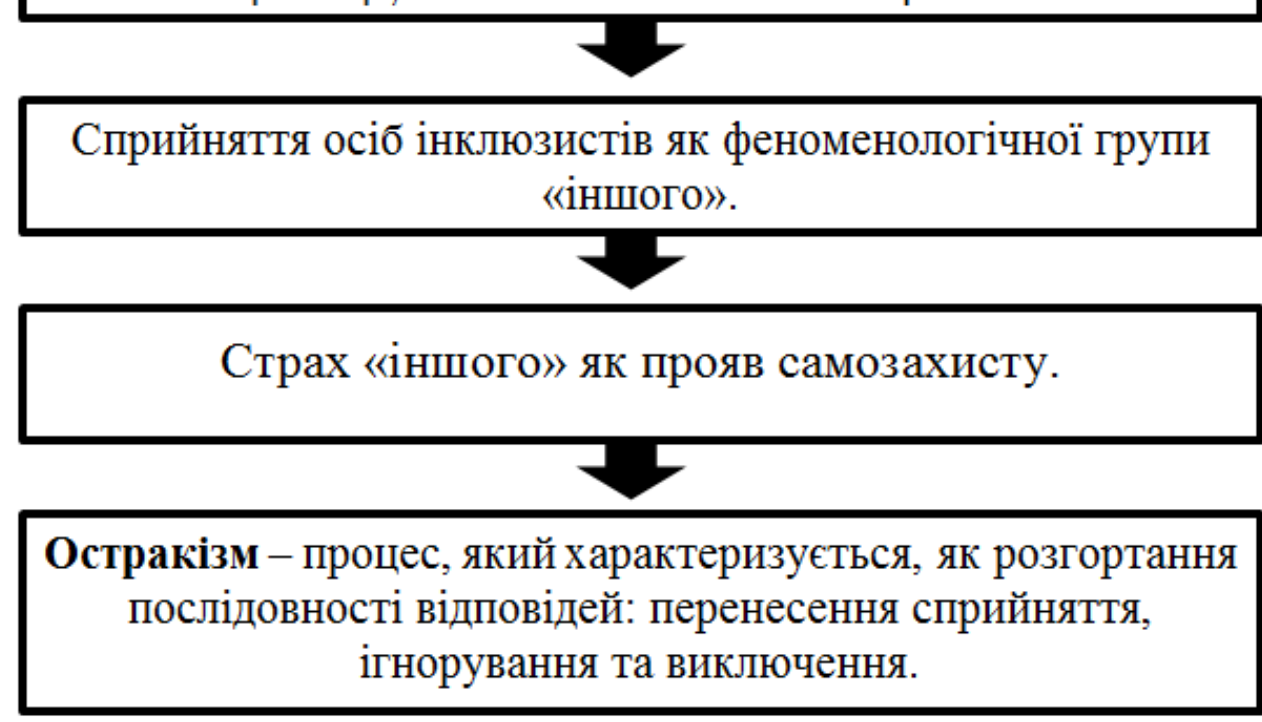

\section{Рис. 1. Механізм формування тенденцій остракізації інклюзивного індивіда}

Підтверджує таке спрямування й О. Леонтьєв, вказуючи на безпідставність ставлення до «чужого» як до ворога. Він стверджує, що саме емоційний відгук на появу в свідомості категорії «чужого» актуалізує образ ворога, який накладається на його носія. У такий спосіб підкреслюється, що реальна поведінка чужинця практично не впливає на когніції, які вибудовуються в свідомості людини, яка його сприймає, тобто негативне ставлення до «чужого» $\epsilon$ безпідставним та упередженим, однак конструкти, що переважають в цей момент, не дозволяють це усвідомити (Masten, 2011: 381 - 388).

Відповідно до дослідження функціонального впливу на інклюзивного індивіда можна вказати на гандикапні прояви остракізму - виключення із соціального середовища під 
впливом психофізіологічних особливостей: мобінг, уникання, насмішки, потурання, наклеп (Коваль, 2002: 201 - 214).

Включення в освіту зараховують до моделі, коли студенти з особливими потребами проводять більшу частину свого часу або весь час із студентами 3 неспеціальними (загальноосвітніми) потребами. Вона виникає в контексті спеціальної освіти 3 індивідуальною освітньою програмою і побудована на уявленні, що для індивідів 3 особливими потребами ефективніше мати зазначений змішаний досвід, аби вони мали більший успіх у соціальній взаємодії, що веде до подальшого успіху в житті (Leary 2005: 381 - 388). Інклюзія відхиляє, але все ще передбачає використання спеціальних шкільних або класних кімнат, щоб відокремити учнів 3 обмеженими можливостями від учнів без обмежень.

Впровадження цих практик різниться, та найчастіше використовується модель включення для вибраних учнів 3 легкими та середніми особливими потребами. Повністю інклюзивні навчальні заклади, які трапляються рідко, не розділяють програми «загальної освіти» та «спеціальної освіти»; натомість школа реструктуризована таким чином, щоб усі учні навчались разом (Гіллі 2004: 197 - 213).

Щоб уникнути формування остракізаторських тенденцій в академічній освіті осіб 3 обмеженими можливостями, необхідна повна різноманітність послуг та ресурсів, які мають включати:

- адекватну підтримку та послуги для особистості;

- спеціально розроблені індивідуальні освітні програми, які будуть враховувати здібності кожного інклюзиста та задовольнятимуть можливість адекватного рівня успішності (Мак Керді 2014: 883 - 893);

- професійний розвиток для всіх залучених викладачів, як загальних, так i спеціальних педагогів;

- розвиток професійних навичок у галузі кооперативного навчання, репетиторства, адаптивного навчального плану;

- співпраця між батьками чи опікунами, викладачами або парапедагогами, спеціалістами, адміністрацією та зовнішніми агенціями (Кирилюк, 2008: 48 - 55).

Враховуючи вище зазначені вимоги, було виділено такі фактори, що можуть визначати успіх інклюзивних класів та попередження розвитку в них остракізаторських тенденцій: партнерство сім'ї та школи; співпраця між загальноосвітніми спеціалістами та дефектологами;д обре побудовані плани, що визначають конкретні умови, модифікації та цілі для кожного студента; узгоджене планування та спілкування між персоналом «загальних» та «особливих потреб» (Домброська, 2011: 71 - 75).

У межах розробленої проблеми можна вказати на низку позитивних наслідків включень, які впливають як на осіб з особливими потребами, так і на інших учасників освітнього простору. Дослідження показали позитивні ефекти для дітей 3 обмеженими можливостями в таких сферах, як досягнення мети індивідуальної освітньої програми, поліпшення комунікативних та соціальних навичок, збільшення позитивних взаємодій 3 однолітками, освітніх результатів та коригування після школи (Наккен 2007: 830 - 845). Позитивні наслідки для дітей-інвалідів включають розвиток позитивного ставлення та сприйняття людей з інвалідністю та підвищення соціального статусу серед однолітків, які не мають інвалідності. Стаючи менш дискримінаційними, учасники без вад, які навчаються в інклюзивних класах, також швидше розвивають комунікативні та лідерські навички (Гастінгс 2003: 87 - 95).

Було проведено кілька досліджень щодо наслідків включення інклюзивних осіб до загальноосвітніх класів. Дослідження 3 питань інклюзії порівнювало інтегрованих та сегрегованих (лише спеціальна освіта) учнів дошкільних закладів і встановило, що інтегровані індивіди прогресували у розвитку соціальних навичок, тоді як сегреговані діти регресували (Голиков 2006: 93 - 99). Ще одне дослідження демонструє вплив на включення в 2-5 класи. Зокрема, було встановлено, що студенти із специфічними вадами навчання 
досягли певних успіхів у навчанні та афективному темпі, у порівнянні з темпом нормальних успішних учнів. Студенти із специфічними порушеннями навчання також продемонстрували покращення самооцінки, а в деяких випадках і покращення мотивації (Андреева, 2009: 74 77). Також дослідження типової аудиторії інклюзії віком від 7 до 11 років показують, як підтримка однолітків в інклюзивному класі може привести до позитивних наслідків для дітей 3 аутизмом. Зокрема, ровесники навчались техніці втручання, щоб допомогти своїм однокласникам-аутистам залишатися зосередженими та виконувати завдання. Дослідження показало, що використання однолітків для втручання, замість вчителів, у класі допомогло студентам з аутизмом значно зменшити поведінку, яка не відповідає завданням. Це також показало, що типові студенти приймали інклюзивну особу з аутизмом як до, так і після введення методів втручання (Баталов, 2010: 101 - 104).

Дотримання принципів ведення інклюзивних осіб в освітньому просторі та забезпечення системного супроводу всього освітянського процесу дають змогу формувати тенденції до толерантного сприйняття «іншого», індивідуальних особистісних проявів та, як наслідок, мінімізації проявів остракізму як в інклюзивному просторі, так і закладах освіти без спеціалізованих класів (Буторина, 2010: 40 - 44).

Висновки і перспективи подальших розвідок. Теоретичний аналіз явища остракізму як феномена інклюзивного простору дав змогу розглянути його як процес, який характеризується як розгортання послідовності відповідей: перенесених, ігнорованих та виключених. Аналізуючи теоретичні відомості, які висвітлюють проблему формування явища остракізму, виявлено, що феномен визначається як виключення, поодинці чи ізольовано, іноді з явними проявами неприязні, а також, що відмова зазвичай відбувається одразу після взаємодії та ізоляції. На основі узагальнення стану розробленої проблеми вказано на деякі ефекти явища остракізації. Зокрема, вона здійснює негативний вплив на молодь більшою мірою, ніж на осіб пубертатного або зрілого віку. Студентство часто страждає з більшою ймовірністю, оскільки особа цього вікового періоду проходить активний інтелектуальний і особистісний розвиток.

Відмічено, що феномен остракізму в просторі освіти може бути виявленим за такими проявами: пригнічений емоційний стан індивіда під час навчального процесу або після перебування в академічній групі; потайливість, сором'язливість, тенденція до замовчування свого особистого життя, відхід від спілкування з сім'єю, друзями та спільної діяльності. Представлено основні причини остракізації інклюзивних індивідів в освітньому просторі, яка $\epsilon$ проявом захисних механізмів на сприйняття «чужого». Здійснено теоретичний аналіз основних аспектів інклюзивного простору, за якого студенти з особливими потребами проводять більшу частину свого часу або весь час із студентами 3 неспеціальними (загальноосвітніми) потребами.

Кожен з аспектів інклюзивного має вводитися у комплексну систему супроводу осіб 3 особливими потребами. Для уникнення формування остракізаторських тенденцій в академічній освіті необхідна повна різноманітність послуг та ресурсів: адекватна підтримка та послуги для особистості; спеціально розроблені індивідуальні освітні програми, які будуть враховувати здібності кожного інклюзиста та задовольнятимуть можливість адекватного рівня успішності; співпраця між батьками чи опікунами, викладачами або парапедагогами, спеціалістами, адміністрацією та зовнішніми агенціями та ін. Виокремлено чинники, що можуть визначати успіх інклюзивних класів та попередження розвитку в них остракізаторських тенденцій: партнерство сім'ї та школи; співпраця між загальноосвітніми спеціалістами та дефектологами; добре побудовані плани, що визначають конкретні умови, модифікації та цілі для кожного студента; узгоджене планування та спілкування між персоналом «загальних» та «особливих потреб». Також висвітлено основні дослідження щодо наслідків включення інклюзивних осіб до загальноосвітніх класів.

Отже, виявлено, що дотримання принципів ведення інклюзивних осіб в освітньому просторі та забезпечення системного супроводу всього освітянського процесу дають змогу формувати тенденції до толерантного сприйняття «іншого», індивідуальних особистісних 
проявів та, як наслідок, мінімізації проявів остракізму як в інклюзивному просторі, так і закладах освіти без спеціалізованих класів.

Подальший розгляд цієї проблеми вбачаємо в більш розгорнутому вивченні основних методів супроводу осіб 3 особливими потребами включення в освітній простір та можливостей формування тенденцій толерантного ставлення через включення у простір освіти інклюзивного індивіда.

\section{СПИСОК ПОСИЛАНЬ}

Андреева, Т. В. (2009). Досуг как форма социокультурной реабилитации инвалидов. Отечественный журнал сочииальной работы, 1, 74-77.

Баталов, А. С. (2010). Использование инклюзивных педагогических технологий в диагностике речевого развития учащихся начальных классов. Начальная школа, 7, 101-104.

Буторина, О. Г. (2010). Об опыте воспитания и обучения детей с ограниченными возможностями здоровья. Воспитание школьников, 7, 40-44.

Гастінгс, П., \& Оакфорд, С. (2003). Ставлення студентів-викладачів до інклюзії дітей 3 особливими потребами. Психологія освіти, 23, 87-95.

Гіллі, Р. М. (2004). Вплив кооперативного навчання на учнів молодших класів під час навчання в малих групах. Освіта та навчання, 14, 197-213.

Голиков, Н. А. (2006). Психолого-педагогическое сопровождение ребенка с особыми образовательными нуждами в условиях массовой школы: дети-инвалиды в общеобразовательной школе. Педагогическая техника, 6, 93-99.

Домбровская, А. Ю. (2011). Социальная адаптация инвалидов. Социологические исследования, 11, 71-75.

Кирилюк, О. М. (2008). Социологический анализ системы реабилитации инвалидов. Отечественный журнал сочииальной работы, 4, 48-55.

Коваль, К. А. (2002). Включення до повного включення: від ортогенезу до патогенезу ідеї. Міжнародний журнал з питань інвалідності, розвитку та освіти, 49, 201-214.

Мак Керді, Е., \& Коул, С. (2014). Використання втручання з боку однолітків для сприяння академічному залученню студентів з аутизмом до загальноосвітніх установ. Журнал аутизму та розладів розвитку, 44, 883-893.

Наккен, К., \& Хаутен, Е. (2007). Дорослі з легкими інтелектуальними вадами: Чи можна покращити здатність до розуміння читання. Журнал досліджень інтелектуальної вади, 51, 830-845.

Jahanzeb, S., Fatima, T., \& Malik, M. A. R. (2018). Supervisor ostracism and defensive silence: a differential needs approach. Eur. J. Work Organ. Psychol. 27, 430-440.

Jones, E. E., Carter-Sowell, A. R., Kelly, J. R., \& Williams, K. D. (2009). I'm out of the loop': ostracism through information exclusion. Group Process. Intergroup Relat. 12, 157-174.

Leary, M. R. (2005). Varieties of interpersonal rejection. Sydney Symposium of Social Psychology series. 4, 35-51.

Masten, C. L. (2011). An fMRI investigation of empathy for 'social pain' and subsequent prosocial behavior. Neuroimage, 55, 381-388.

Stroud, L. R., Tanofsky-Kraff, M., Wilfley, D. E., \& Salovey, P. (2000). The Yale Interpersonal Stressor (YIPS): affective, physiological, and behavioral responses to a novel interpersonal rejection paradigm. Ann. Behav. Med, 22, 204-212.

\section{REFERENCES}

Andreeva, T. V. (2009). Dosug kak forma sotsiokul'turnoy reabilitatsii invalidov [Leisure as a form of socio-cultural rehabilitation of the disabled]. Domestic Journal of Social Work, 1, 74-77. [in Russian]. 
Batalov, A. S. (2010). Ispol'zovaniye inklyuzivnykh pedagogicheskikh tekhnologiy v diagnostike rechevogo razvitiya uchashchikhsya nachal'nykh klassov [The use of inclusive pedagogical technologies in the diagnosis of speech development of primary school students]. Primary School, 7, 101-104. [in Russian].

Butorina, O. G. (2010). Ob opyte vospitaniya i obucheniya detey s ogranichennymi vozmozhnostyami zdorov'ya [About the experience of raising and educating children with disabilities]. Education of schoolchildren, 7, 40-44. [in Russian].

Hastings, P., \& Oakford, S. (2003). Stavlennya studentiv-vykladachiv do inklyuziyi ditey z osoblyvymy potrebamy [The attitude of student teachers to the inclusion of children with special needs]. Psychology of Education, 23, 87-95. [in Ukrainian].

Gilly, R. M. (2004). Vplyv kooperatyvnoho navchannya na uchniv molodshykh klasiv pid chas navchannya $\mathrm{v}$ malykh hrupakh [The impact of cooperative learning on primary school students while learning in small groups]. Education and Training, 14, 197-213. [in Ukrainian].

Golikov, N. A. (2006). Psikhologo-pedagogicheskoye soprovozhdeniye rebenka s osobymi obrazovatel'nymi nuzhdami $\mathrm{v}$ usloviyakh massovoy shkoly: deti-invalidy $\mathrm{V}$ obshcheobrazovatel'noy shkole [Psychological and pedagogical support of a child with special educational needs in a mass school: children with disabilities in a comprehensive school]. Pedagogical technique, 6, 93-99. [in Russian].

Dombrovskaya, A. Yu. (2011). Sotsial'naya adaptatsiya invalidov [Social adaptation of the disabled]. Sociological Research, 11, 71-75. [in Russian].

Kirilyuk, O. M. (2008). Sotsiologicheskiy analiz sistemy reabilitatsii invalidov [Sociological analysis of the rehabilitation system for the disabled]. Domestic Journal of Social Work, 4, 48-55. [in Russian].

Koval, K. A. (2002). Vklyuchennya do povnoho vklyuchennya: vid ortohenezu do patohenezu ideyi [Inclusion to full inclusion: from orthogenesis to the pathogenesis of the idea]. International Journal of Disability, Development and Education, 49, 201-214. [in Ukrainian].

McCurdy, E., \& Cole, S. (2014). Vykorystannya vtruchannya z boku odnolitkiv dlya spryyannya akademichnomu zaluchennyu studentiv z autyzmom do zahal'noosvitnikh ustanov [Using peer intervention to promote the academic involvement of students with autism in secondary schools]. Journal of Autism and Developmental Disorders, 44, 883-893. [in Ukrainian].

Nakken, K., \& Houten, E. (2007). Dorosli z lehkymy intelektual'nymy vadamy: Chy mozhna pokrashchyty zdatnist' do rozuminnya chytannya [Adults with mild intellectual disabilities: Can the ability to understand reading be improved]. Journal of Intellectual Disability Research, 51, 830-845. [in Ukrainian].

Jahanzeb, S., Fatima, T., \& Malik, M. A. R. (2018). Supervisor ostracism and defensive silence: a differential needs approach. Eur. J. Work Organ. Psychol. 27, 430-440. [in English].

Jones, E. E., Carter-Sowell, A. R., Kelly, J. R., \& Williams, K. D. (2009). I'm out of the loop: ostracism through information exclusion. Group Process. Intergroup Relat. 12, 157-174. [in English].

Leary, M. R. (2005). Varieties of interpersonal rejection. Sydney Symposium of Social Psychology series. 4, 35-51. [in English].

Masten, C. L. (2011). An fMRI investigation of empathy for 'social pain' and subsequent prosocial behavior. Neuroimage, 55, 381-388. [in English].

Stroud, L. R., Tanofsky-Kraff, M., Wilfley, D. E., \& Salovey, P. (2000). The Yale Interpersonal Stressor (YIPS): affective, physiological, and behavioral responses to a novel interpersonal rejection paradigm. Ann. Behav. Med, 22, 204-212. [in English]. 


\title{
OSTRACISM AS A PHENOMENON OF INCLUSIVE SPACE
}

\author{
Victoria Nazarevich, \\ $\mathrm{PhD}$ (Psychology), \\ Associate of the Department of Age and Pedagogical Psychology \\ of Rivne State University of Humanities \\ http://orcid.org/ 0000-0002-0111-7070 \\ DOI https://doi.org/10.35619/praprv.v1i15.193
}

\begin{abstract}
The article examines the phenomenon of ostracism as a phenomenon of inclusive space. Particular attention is paid to intolerance of individuals with inclusive manifestations that exist in society, due to the interaction between people of different nationalities, religions, professional orientation, and certain physical characteristics.

The author reveals the understanding of the ostracism phenomenon in the space of education as a process that is characterized as the development of a sequence of responses, transferred, ignored, and excluded. And also, as an exception, alone or in isolation, sometimes with obvious manifestations of hostility. The model and features of the manifestations of the phenomenon in the space of inclusive education are revealed; they include issues such as depressed emotional state of the individual during the educational process or after being in an academic group; secrecy, shyness, tendency to silence one's personal life; avoidance of communication with family, friends and joint activities, avoiding discussions about the university or other educational environment.

It is determined that the main reason for the ostracism of inclusive people in the educational environment is the perception of people with disabilities as a phenomenological group of "other", and the reason for this approach is the mechanism of fear of "other" as a manifestation of selfdefense.
\end{abstract}

The handicap manifestations of ostracism are indicated - exclusion from the social environment under the influence of psycho-physiological features: mobbing, avoidance, ridicule, indulgence, slander. The main conditions of the organization of the inclusive process when working with ostracizing manifestations in the educational sphere are highlighted: partnership of family and school; cooperation between secondary and special educators; coordinated planning and communication between "general" and "special needs" staff.

There are a number of positive effects of inclusions that affect both people with special needs and other participants in the educational space.

It is concluded that adherence to the principles of inclusive people in the educational space and providing systematic support of the entire educational process allows the formation of tendencies to tolerant perception of "other", individual personal manifestations and, as a consequence, minimizing ostracism in inclusive space and educational institutions without specialized classes. We see further consideration of this problem in a more detailed study of the main methods of accompanying people with special needs and the possibilities of forming trends of tolerant attitude through the inclusion of an inclusive individual in the educational space.

Key words: inclusion, inclusive space, tolerance, ostracism, manifestations of ostracism, minimization of ostracism, educational work. 